\title{
Effects of plant growth regulators and growing media on propagation and field establishment of Stevia rebaudiana: a medicinal plant of commerce
}

\author{
K. Abha Manohar ${ }^{1,3}$, Gopal Shukla ${ }^{1 *} \mathbb{C}$, Bidhan Roy $^{2}$ and Sumit Chakravarty ${ }^{1}$
}

\begin{abstract}
Background: Stevia rebaudiana is an economically important medicinal plant that has generated interest among the growers and pharmacologists in terms of its industrial or pharmaceutical value. For the mass production of the seedlings, easy and convenient techniques are lacking while, micro propagation was reported promising but still out of reach at farm level. The unavailability of quality planting materials due to non-viable seeds is restricting its mass commercial scale cultivation. The present study was therefore attempted to standardize the plant growth regulators and growing media to standardize the vegetative propagation protocol through cuttings for its mass multiplication in Terai region of West Bengal, India.

Methods: Growing media (soil, FYM, saw dust and sand) as sole and in combination and growth hormones (IAA, IBA and NAA in different concentration and a commercial formulation i.e. Totoroot $\odot$ with different exposure time) were compared with control (i.e. sole soil and no hormone treatment, respectively) to standardize the nursery protocol of Stevia.

Results: Sand used as sole was found the best growing media for survival and growth of cuttings while, cuttings treated with commercial growth hormone formulation for 5 mins was best. Cuttings treated with commercial growth hormone formulation performed significantly better in the field with respect to survival, growth and production of leaves.

Conclusion: The study recommends the use of sole sand media and commercial growth hormone formulation with 5 mins exposure time for mass nursery production of Stevia cuttings in Terai zone of West Bengal due to their better performance both in the nursery and after transplanting in the field.
\end{abstract}

Keywords: Asexual propagation, Growth regulators, Rooting media, Stevia

\section{Background}

Cultivation of commercially important medicinal and aromatic plants (MAPs) is in high demand as the global community is favoring green and herbal oriented

*Correspondence: gopalshukla12@gmail.com

1 Department of Forestry, Uttar Banga Krishi Viswavidyalaya, Pundibari, 736165 Cooch Behar, West Bengal, India

Full list of author information is available at the end of the article approach. There is population decline in medicinal plants with increasing demand of plant derived drugs (Ghani 2003) as well as limited knowledge regarding wild medicinal plants (Grigoriadou et al. 2019). Thus an urgent need to develop and implement regeneration protocol, conservation strategies for over exploited MAP species with high commercial value is inevitable. Medicinal plants are of great interest to the researchers as most of the drug 
industries depend on plants for the production of pharmaceutical combinations.

Stevia rebaudiana as one of the priced medicinal plant, popularly known as 'sweet herb or honey leaf is a perennial herb belong to the Asteraceae family is highly useful for diabetic (type II), due to its calorie free sweetening property (Siegel et al. 2008). Its major chemical components are steviosides, rebaudioside and steviolbioside. The sweetening compound present is 300 times sweeter than sucrose (Joseph and George 2019). The worldwide apprehension for chronic degenerative diseases and quest for healthy foods in the developed and developing nation have stimulated a strong interest in the plant as a substitute to sucrose and artificial sweeteners (Yadav et al. 2011). In the coming years the production of stevia leaves will overcome the demand and supply problem but need to explore the new arenas for successful production of the leaves (Oviedo-Pereira et al. 2015). In India stevia has generated interest among plant biotechnologists and pharmacologists in terms of its industrial or commercial and pharmaceutical importance (Abdul Razak et al. 2014; Bisht et al. 2017; Das and Mandal 2010; Das et al. 2011; Debnath 2008; Jain et al. 2009; Gantait et al. 2015; Patwardhan et al. 2016). As regard to diabetic market in India, stevia will give good remuneration to the farmers (Hossain et al. 2017).

Stevia is conventionally propagated by seeds and stem cuttings but propagation through seed is very scanty and not efficient due to low fertility or self-incompatibility, highly sensitive towards biotic stresses (Magangana et al. 2018; Oviedo-Pereira et al. 2015; Rock-Okuyucu et al. 2016; Yadav et al. 2011), which produced uneven and heterogeneous plant population. Vegetative mass multiplication techniques can be effective in developing suitable popular propagation protocols for Stevia also (Abdul Razak et al. 2014; Jain et al. 2009). Protocols and methods for tissue culture were already standardized by number of researchers (Das and Mandal 2010; Lemus-Mondaca et al. 2012; Pande and Gupta 2013; Yadav et al. 2011) but not yet popular due to their high cost and resources involvement (Khalil et al. 2014; Pigatto et al. 2018; Sivaram and Mukundam 2003). Vegetative propagation through stem cutting is a viable alternative for propagation of the species but further standardization is required to achieve high success at field level (De Carvalho and Zaidan 1995; Kassahun and Mekonnen 2011). Concentration of hormone, time of cutting and environmental conditions is the major determinants of adventitious rooting and survivability of stem cuttings (Hartmann et al. 2010). Homogenous, porous and aseptic growing medium is required for efficient root development (Mendes et al. 2013).
In order to commercialize the species, information on growth regulators, growing media, seedling vigour, time and duration of cutting is also important (Ingle and Venugopal 2009; Rajashekara 2004). However, information on naturally available, cost effective rooting media, bio-inoculants, and their interaction with the growing conditions for multiplication of stevia is scarce. Farmers at sub-humid foothills in Indian Eastern Himalayas are now diversifying their farming systems, of which medicinal plant like Stevia rebaudiana is one of the components. Thus, there is a pressing need to standardize the vegetative protocols of the species for production of superior planting materials in the region towards its large scale cultivation and conservation. However, the region lacks quality planting materials of the species. Keeping the lack of availability of quality planting materials of the species at Terai zone of West Bengal in view the present study was carried to standardize the growing media and growth regulators for production of quality planting materials of the species within short period of time.

\section{Materials and methods \\ Experimental site and time}

The present study was carried out in central forest nursery under Department of Forestry, Uttar Banga Krishi Viswavidyalaya, Pundibari, West Bengal, India during Feb, 2018 to June, 2020. The study site is located at $26^{\circ} 19^{\prime} 86^{\prime \prime} \mathrm{N}$ latitude and $89^{\circ} 23^{\prime} 53^{\prime \prime} \mathrm{E}$ longitude at an elevation of $43 \mathrm{~m}$ above mean sea level with sub-tropical climate and lies in the Terai region of West Bengal. The mean monthly relative humidity ranged from 80.0 to $86.5 \%$ and the total rainfall received was $200-300 \mathrm{~cm}$ from south-west monsoon of which 80 per cent is received from June to August. The summer and winter temperature are mild with $34{ }^{\circ} \mathrm{C}$ as the highest in the month of May while the lowest temperature is $7.5^{\circ} \mathrm{C}$ in the month of January.

\section{Collection of cutting and setting of experiment}

The stem cuttings of Stevia rebaudiana were collected from one year old healthy and uniform plants maintained by the Department of Forestry, Uttar Banga Krishi Viswavidyalaya, Pundibari and cutting of the apical portion of the branch was used as planting material in the experiments. Uniform and healthy cuttings were used for the experiment purposes. In each treatment 180 cuttings of $6 \mathrm{~cm}$ length were subjected to different combination of four growing media and four growth regulators (including a commercial product) to separately analyze the effect of the growing media and growth regulators on sprouting and survival of the stevia cuttings. The cuttings were planted at a depth of one centimeter in the growing media. After planting of cuttings the polybags were 
kept in shade house. The cuttings in both the experiments were planted in polybags of size $5 \mathrm{~cm} \times 8 \mathrm{~cm}$. The effect of both growing media and growth regulators were analyzed by recording observations on rooting of the cuttings (i.e. number of cuttings with roots developed) and number of roots per cutting. The cuttings were kept in the growing media for 30 days to record observations. The growing media found best in this treatment was used in the next experiment to analyze the response of stevia cuttings to various growth regulators.

\section{Growing media and growth regulators}

\begin{tabular}{|c|c|c|}
\hline \multirow{2}{*}{$\frac{\text { Treatments }}{\text { Growing media }}$} & \multicolumn{2}{|c|}{ Treatments } \\
\hline & & \\
\hline $\mathrm{T}_{1}$ Soil as control & $\mathrm{T}_{6}$ & $\begin{array}{l}\text { Soil, sand and FYM in equal } \\
\text { proportion }\end{array}$ \\
\hline $\begin{array}{ll}\mathrm{T}_{2} & \text { Soil and sand in equal pro- } \\
\text { portion }\end{array}$ & $\mathrm{T}_{7}$ & $\begin{array}{l}\text { Soil and FYM in equal propor- } \\
\text { tion }\end{array}$ \\
\hline $\begin{array}{l}\mathrm{T}_{3} \text { Two parts sand and one part } \\
\text { soil }\end{array}$ & $\mathrm{T}_{8}$ & $\begin{array}{l}\text { Two parts soil, one part sand } \\
\text { and one part saw dust }\end{array}$ \\
\hline $\begin{array}{l}\mathrm{T}_{4} \begin{array}{l}\text { Two parts soil and one part } \\
\text { sand }\end{array}\end{array}$ & $T_{9}$ & Sand \\
\hline $\begin{array}{l}\mathrm{T}_{5} \text { Two parts soil and one part } \\
\text { saw dust }\end{array}$ & $\mathrm{T}_{10}$ & $\begin{array}{l}\text { Three part soil and one part } \\
\text { sand }\end{array}$ \\
\hline \multicolumn{3}{|l|}{ Growth regulator } \\
\hline $\begin{array}{l}\mathrm{T}_{1} \text { Cuttings dipped in IBA } \\
50 \text { ppm for } 5 \text { min }\end{array}$ & $\mathrm{T}_{8}$ & NAA 100 ppm for 5 min \\
\hline $\begin{array}{l}\mathrm{T}_{2} \text { Cuttings dipped in IBA } \\
100 \text { ppm for } 5 \text { min }\end{array}$ & $\mathrm{T}_{9}$ & NAA 150 ppm for 5 min \\
\hline $\begin{array}{l}\mathrm{T}_{3} \text { Cuttings dipped in IBA } \\
150 \text { ppm for } 5 \text { min }\end{array}$ & $\mathrm{T}_{10}$ & $\begin{array}{l}\text { Cuttings smeared in *a pow- } \\
\text { dery commercial formulation } \\
\text { for } 1 \text { min }\end{array}$ \\
\hline $\begin{array}{l}\mathrm{T}_{4} \text { Cuttings dipped in IAA } \\
50 \text { ppm for } 5 \mathrm{~min}\end{array}$ & $\mathrm{~T}_{11}$ & $\begin{array}{l}\text { Cuttings smeared in a powdery } \\
\text { commercial formulation for } \\
3 \mathrm{~min}\end{array}$ \\
\hline $\begin{array}{l}\mathrm{T}_{5} \text { Cuttings dipped in IAA } \\
100 \text { ppm for } 5 \mathrm{~min}\end{array}$ & $\mathrm{~T}_{12}$ & $\begin{array}{l}\text { Cuttings smeared in a powdery } \\
\text { commercial formulation } 5 \text { min }\end{array}$ \\
\hline $\begin{array}{l}\mathrm{T}_{6} \text { Cuttings dipped in IAA } \\
150 \mathrm{ppm} \text { for } 5 \mathrm{~min}\end{array}$ & $\mathrm{~T}_{13}$ & Control (without any hormone) \\
\hline $\begin{array}{l}\mathrm{T}_{7} \text { Cuttings dipped in NAA } \\
50 \mathrm{ppm} \text { for } 5 \mathrm{~min}\end{array}$ & & \\
\hline
\end{tabular}

*Composition of toto root (IBA, NAA, Phosphate solubilizing bacteria, $\mathrm{H}_{3} \mathrm{BO}_{3}$; vitamins, surfactant and talc but concentration is commercial secret)

\section{Field performance}

Healthy and uniform rooted seedlings in each treatment from growth regulator experiment were transplanted in the field beds after 30 days to record the performance under nursery condition laid in randomized block design replicated thrice. The observations recorded for analyzing the field performance of the seedlings were survivability, shoot length, number of branches, number of leaves, number of roots, fresh leaf weight, fresh shoot weight and fresh root weight on the day of transplanting (i.e. initial or 0 DAT), 90 DAT and 150 DAT. The. A total of 50 seedlings were transplanted in the field plots. Every treatment was assigned with a field plot of size $1.2 \mathrm{~m} \times 2.5 \mathrm{~m}$ with five rows of 10 seedlings in each row. Both the growing media and growth regulator experiments were conducted for two consecutive years. Standard agronomic practices for Stevia were followed in the field experiment. Three seedlings were randomly selected for recording growth observations and were expressed as mean of three seedlings. For field performance plants were harvested from centre of the plot excluding the edges at all sides.

\section{Data analysis}

The experimental data recorded for survival experiments and field performance of $S$. rebaudiana were subjected to the variance analysis through complete randomized block design and randomized block design, respectively and the significance of different sources of variations were tested following standard procedures of LSD (Least Squared Difference Test) at 0.05 probability level. All these analysis were performed using SPSS Base 10.0 version software package (Copy write 1997, by SPSS Inc. USA).

\section{Results and discussion}

Effect of growing media on rooting

Growing media significantly influenced the rooting of stevia cuttings (Fig. 1). The mean (of two years) number of cuttings with roots was in the range of $24.0-42.33 \%$ i.e. minimum number of cuttings with roots was found with soil as growing media $\left(T_{1}\right)$ and maximum number of cuttings with roots was with sand as growing media $\left(\mathrm{T}_{9}\right)$. Moreover composite growing media with higher proportion of soil $\left(\mathrm{T}_{4}\right.$ and $\left.\mathrm{T}_{8}\right)$ was recorded with lesser number of cuttings with roots as compared to composite media with higher proportion of FYM, saw dust and sand. Sand media due to lesser compaction and more aeration helped in root formation and growth. Porosity and better aeration in sand might gave momentum for development of root structure (Ogao-Ogao et al. 2017). Alternatively media with only soil were more compact with lesser aeration didn't supported root initiation.

Increasing ratio of sand in growing media $\left(\mathrm{T}_{10}\right)$ thus increased the chances of root formation of stevia cuttings. On the contrary, rooting of stevia cuttings with media having equal proportion of soil, sand and FYM or soil and FYM was statistically similar with pure soil media. Sand as rooting substrate with humid environmental conditions of the Terai region provided proper conditions for initiation, growth and development of roots which helped better cutting establishment. Humid climatic condition was reported with better cutting establishment due to better root development as 
compared to arid climate (Pigatto et al. 2018; Smitha and Umesha 2012) due to favourable rhizogenic process (Zuffellato-Ribas and Rodrigues 2001).

Similarly growing media used also significantly influenced the number of roots per stevia cuttings also (Fig. 2). Number of roots per cutting ranged from 4.23 to 6.84 (mean of two years). Sand media $\left(\mathrm{T}_{9}\right)$ was observed minimum number of roots while, growing media with equal proportion of soil and FYM produced highest number of roots per cutting $\left(T_{7}\right)$. Number of roots in stevia cuttings with different growing media exhibited a reverse pattern with rooting of the cuttings. Rooting and thereafter growth of the cuttings requires continuous supply of nutrients from the growing media. Successful propagation of this plant was reported with cuttings which require growing media containing all essential ingredients for plant growth and development (Murthy et al. 2010; Smitha and Umesha 2012; Vessey 2003) as stevia seeds are very minute and delicate which are difficult to handle (Castañeda-Saucedo et al. 2020; Ingle and Venugopal 2009; Khalil et al. 2014; Ogao-Ogao et al. 2017; Pigatto et al. 2018; Rajashekara 2004; Smitha and Umesha 2012). Providing right growing media was reported to improve yield and quality of stevia also (Koppad and Gouda 2010; Umesha et al. 2011).

Growing media capable of supplying nutrients are required for uninterrupted growth of cuttings and further development. Soil alone or mixed with FYM is inherently fertile with nutrients that supports rooting and continuous growth of the cuttings (Aquino 2011; Smitha and Umesha 2012; Cedo et al. 2014; Ogao-Ogao et al. 2017). Growing media having good amount of nutrient, and water retention capacity is ideal for rooting of cuttings (Hartmann et al. 2010; Pigatto et al. 2018; Shukla et al. 2007a, b). However, mixing of either sand or saw dust didn't supported rooting as was evidenced from the lesser number of roots per cuttings than soil or FYM media. Higher rooting in stevia cutting using soil or sand media fortified with nutrient rich material instead of sole soil or sand medium was also earlier reported (Smitha and Umesha 2012). This indicates that Stevia requires organic materials in their nourishment (Ogao-Ogao et al. 2017; Shahid et al. 2014). FYM mixed with soil improved the growing media structure, nutrient availability, soil microbes and improved water retention while, reducing its compaction (Fidanza et al. 2010; Ogao-Ogao et al. 2017). Mixing FYM with soil favourably enhanced root surface area for absorption of nutrients and water to the growing stevia seedlings (Asghari 2018; Jeffries et al. 2003; Mandal et al. 2013; Pal et al. 2015). Further, incorporating FYM in the medium elevated its nutrient status which complements photosynthesis thus increasing metabolites in the system to initiate better rooting of the cuttings (Giri et al. 2003).

\section{Effect of growth regulators on rooting}

Application of growth regulators in different combination significantly influenced the rooting of stevia cuttings (Fig. 3). Considering the mean of 2 years application of Totoroot ${ }^{\circledR}$ for three minutes $\left(\mathrm{T}_{11}\right)$ significantly improved the rooting of stevia cuttings $(68.33 \%)$ as compared to control $\left(\mathrm{T}_{13}-30.0 \%\right.$ survival) and other hormonal treatments as well $\left(\mathrm{T}_{1-10,12}-31.84-61.67 \%\right)$. The next best treatment in terms of rooting of cuttings was Totoroot ${ }^{\circledR}$ for 5 mins $\left(\mathrm{T}_{12}\right)$ recorded with rooting of $61.67 \%$ cuttings. Other growth regulators i.e. IAA, IBA and NAA in

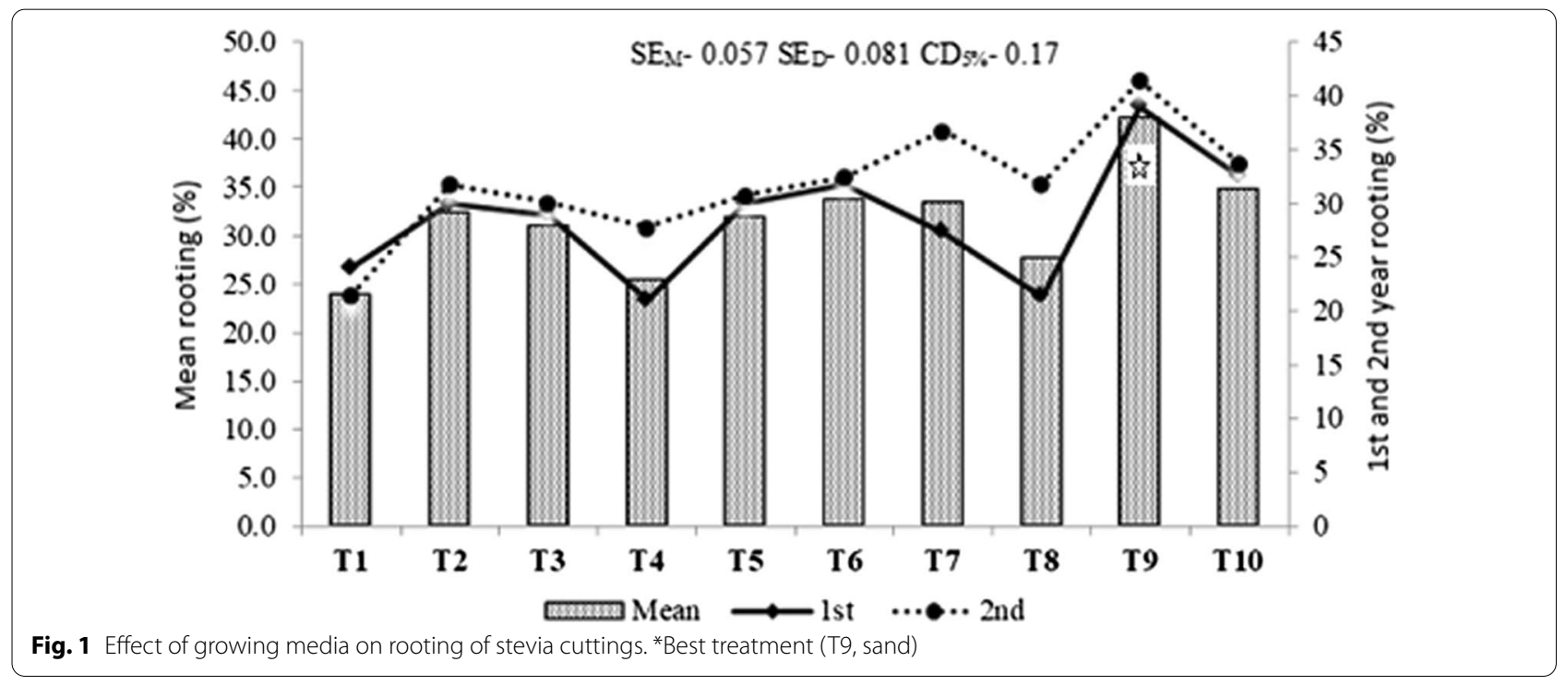




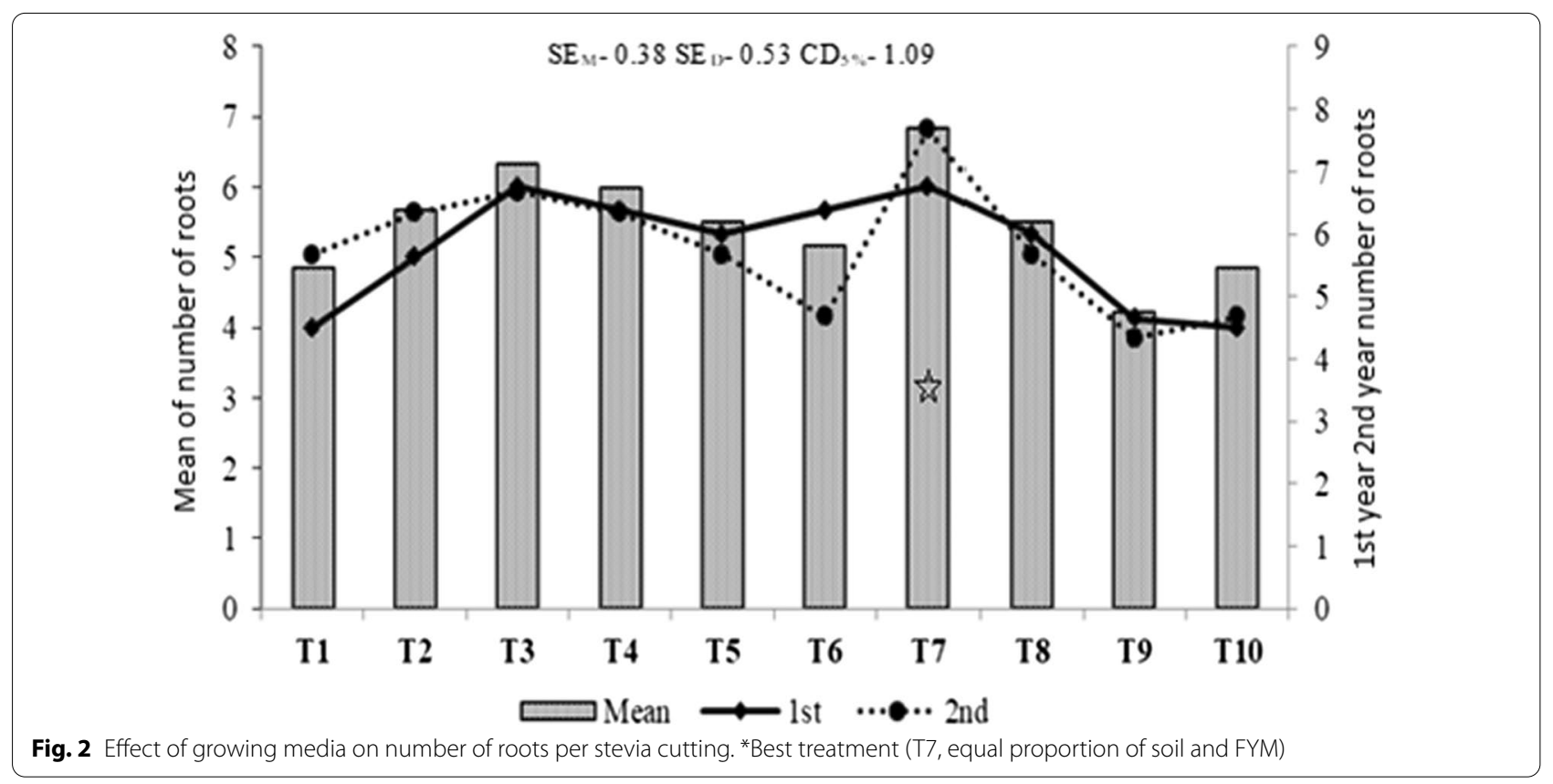

different concentrations though significantly improved rooting of cuttings i.e. 31.84-48.33\% (except treatment $\mathrm{T}_{8}$ which was statistically at par with control) but was not good enough to be compared with rooting of cuttings $(40.0-68.33 \%)$ subjected to Totoroot ${ }^{\circledR}$ treatment.

Totoroot $^{\circledR}$ is a commercial formulation with composition of IBA, NAA, Phosphate solubilizing bacteria (PSB), $\mathrm{H}_{3} \mathrm{BO}_{3}$; vitamins, surfactant and talc which supported highest rooting of cuttings than sole application of any growth regulators in different concentrations. This may be due to the combined effect of the growth regulators, nutrients and improved use efficiency of used hormones as surfactant in the formulation might have increased the adsorption and absorption of hormonal molecules on the contact surface of the cutting and its transport into the site of action in the cutting. The formulation exogenously supplemented synthetic auxin which might have influenced formation of rooting in stevia cuttings (Zuffellato-Ribas and Rodrigues 2001) as synthetic hormones mobilize nutrients for root formation when applied at the base of the cuttings (Magevski et al. 2011). Application of optimal concentration of plant growth regulators in cuttings was reported responsible for stimulating the growth and differentiation of the tissues and improving the rooting along with endogenous level of hormones and other rooting promoters (Hartmann et al. 2010). From the results of present study, it was distinct that low concentration (i.e. 50 and 100 ppm) of IBA and NAA didn't influence rooting of the cuttings as was observed with $150 \mathrm{ppm}$ indicating sub-optimal level of hormones used.
In contrast to the present study earlier studies (De Carvalho and Zaidan 1995; Kassahun and Mekonnen 2011; Khalil et al. 2014; Smitha and Umesha 2012) used higher concentrations of auxin even up to $2000 \mathrm{ppm}$. The present study recorded higher rooting of cuttings with lower concentration of auxin based hormones (up to $150 \mathrm{ppm}$ ) as compared to $10-40 \%$ rooting by using $500-2000 \mathrm{ppm}$ IBA (Pigatto et al. 2018).

Application of growth regulators in different combination significantly influenced the number of roots per stevia cutting (Fig. 4). Response of growth regulators as sole and in combination exhibited varied response though they produced significantly more number of roots per cutting than the control i.e. without any growth regulator. Considering the mean of two years the highest number of roots per cutting i.e. 9.00 was obtained with application of $50 \mathrm{ppm}$ NAA $\left(\mathrm{T}_{7}\right)$ followed by application of $150 \mathrm{ppm}$ IBA $\left(\mathrm{T}_{3}-7.83\right), 50 \mathrm{ppm} \mathrm{IBA}\left(\mathrm{T}_{1}-7.0\right)$ and Totoroot $^{\circledR}$ for 5 $\min \left(\mathrm{T}_{12}-7.0\right)$. The results indicate that low concentration of NAA was better for root formation while, increasing the concentration decreased the number of roots per cuttings of stevia. Similarly earlier studies on $S$. rebaudiana reported rooting of cuttings but with application of higher concentration of growth regulators (Khalil et al. 2014; Koppad et al. 2006) while, in the present study higher number of roots per cuttings were recorded in low concentration which can be attributed to humid climatic condition of the study areas (Pigatto et al. 2018; Smitha and Umesha 2012; Zuffellato-Ribas and Rodrigues 2001). 


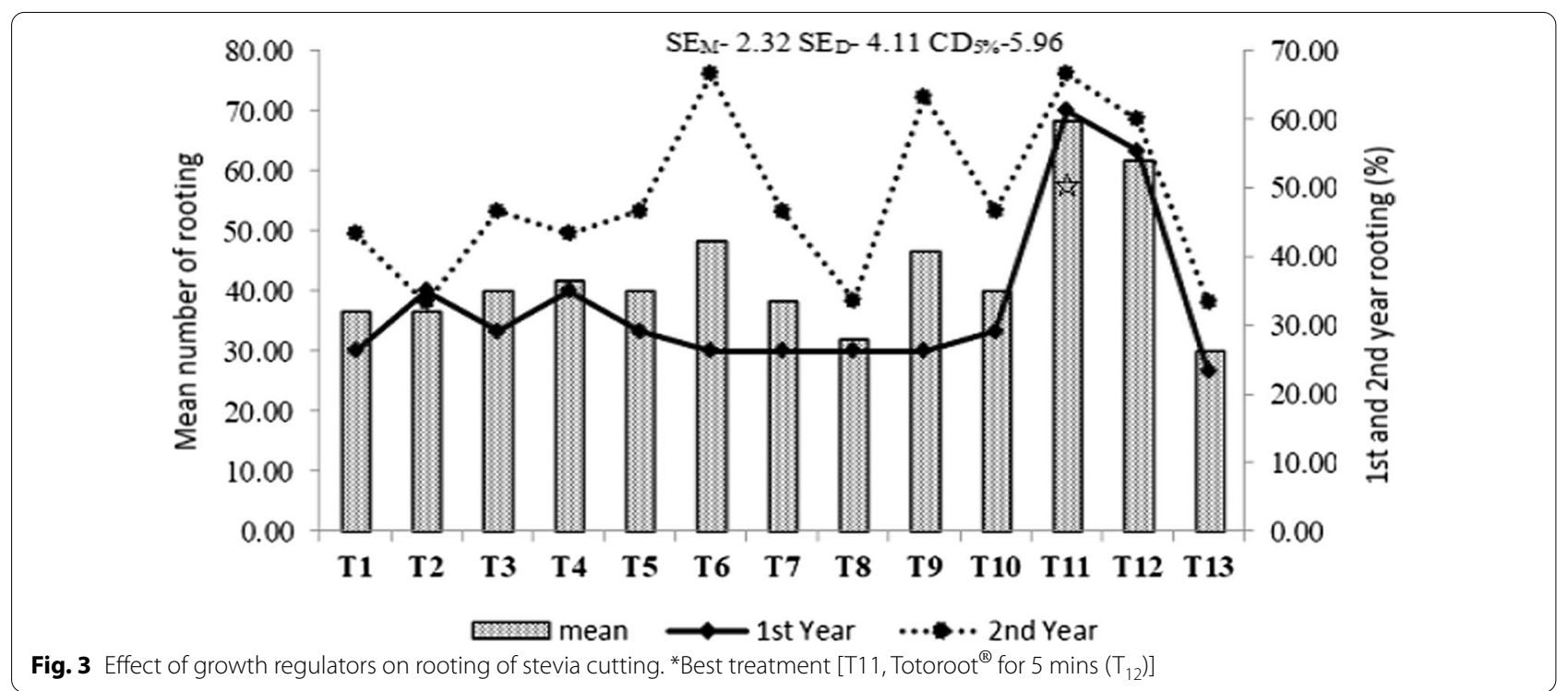

\section{Effect of growth regulators on field performance} Field survival

Field survival of stevia rooted cuttings was more than $80 \%$ with all the treatments (Fig. 5). Even with no hormonal application (control i.e. $\mathrm{T}_{13}$ ) the survival of stevia was $80 \%$ which is though significantly lesser than all hormonal treatments except treatment $\mathrm{T}_{7}$ (NAA $50 \mathrm{ppm}$ ) with cutting survival of $81.67 \%$. Highest plant survival of 98.83\% was recorded with application of $100 \mathrm{ppm}$ NAA $\left(\mathrm{T}_{8}\right.$ ) followed by $\mathrm{T}_{2}$ (IBA $100 \mathrm{ppm}$ ) and $\mathrm{T}_{6}$ (IAA $150 \mathrm{ppm}$ ) each with $93.33 \%$ plant survival; $\mathrm{T}_{1}$ (IBA $50 \mathrm{ppm}$ ), $\mathrm{T}_{4}$ (IAA $50 \mathrm{ppm}$ ), $\mathrm{T}_{5}$ (IAA $100 \mathrm{ppm}$ ), $\mathrm{T}_{10}$ (Totoroot $^{\circledR}$ for one minute) \& $\mathrm{T}_{12}$ (Totoroot ${ }^{\circledR}$ for $5 \mathrm{~min}$ ) each with $91.67 \%$ plant survival; $\mathrm{T}_{9}$ (NAA $150 \mathrm{ppm}$ ) with $90 \%$ plant survival and $\mathrm{T}_{11}$ (Totoroot ${ }^{\circledR}$ for three minute) with $85 \%$ plant survival. All these applied hormones including Totoroot ${ }^{\circledR}$ are growth promoters thus aided in better growth and development of the rooted cuttings ensuring survival of the plant better than untreated cuttings in the field.

\section{Growth attributes}

The mean of two years data for effect of growth regulators on shoot length at 30,90 and 150 DAT were recorded significant (Table 1).

Longest shoot $(22.54 \mathrm{~cm})$ was reported on 30 DAT when the cuttings were treated with Totoroot ${ }^{\circledR}$ for $5 \mathrm{~min}$ (T12) which is at par with T8, T4, T11, T7, T1 and T10. Totoroot ${ }^{\circledR}$ for 5 min (T12) was also established to be the best treatment for enhancement of shoot length of cutting at 90 and $150 \mathrm{DAT}$. The results indicated that the application of Totoroot ${ }^{\circledR}$ significantly increased the shoot length of stevia plants as compared to the application of sole IAA, IBA and NAA. Treating stevia cutting with
Totoroot $^{\circledR}$ for 5 mins $\left(T_{12}\right)$ produced plants with longest shoots of $47.93 \mathrm{~cm}$ in the field at 150 DAT and was significantly better than all other treatments. The next best applications in terms of shoot length at 150 DAT were IAA $150 \mathrm{ppm}\left(\mathrm{T}_{6}\right)$, Totoroot ${ }^{\circledR}$ for one minute $\left(\mathrm{T}_{10}\right)$ and NAA $100 \mathrm{ppm}\left(\mathrm{T}_{8}\right)$ recorded with $42.93 \mathrm{~cm}, 41.6 \mathrm{~cm}$ and $40.23 \mathrm{~cm}$ long shoots, respectively. All these treatments were statistically similar with each other.

Number of branches and number of mean leaves per stevia plant in the field at 30, 90 and 150 DAT for two years was significantly influenced by the application of growth regulators (Table 2). The mean number of branches and leaves of 2 years in Stevia plants were significantly more with growth regulator applications than control.

Totoroot $^{\circledR}$ application for 5 min $\left(\mathrm{T}_{12}\right)$ was recorded with maximum number of branches (17.66) and leaves (159.35) per plant in the field at 150 DAT. Significantly higher number of branches and number of leaves were recorded in $\mathrm{T}_{12}$ (Totoroot $^{\circledR}$ for $5 \mathrm{~min}$ ). However, the number of branches was highest at 90 DAT when treated with IAA $150 \mathrm{ppm}$ for $5 \mathrm{~min}$. T12 was at par with T10 at 30 DAT at 30 DAT and T12 at par with T3 at 150 DAT for number of branches per plant. T12 was at par with T3, T4, T6 and T11 at 90 DAT; T12 was at par with T5, T6 and T9 at 90 DAT; T12 was at par with T3, T6 and T9 for number of leaves per plant.

The number of branches and number of leaves per plant had positive correlation. It was noted that Toto$\operatorname{root}^{\circledR}$ for $5 \mathrm{~min}$ had enhanced the number of branches and number of leaves per plant (Table 2). More the length of the shoots, more the branches produced and ultimately more number of leaves produced. 

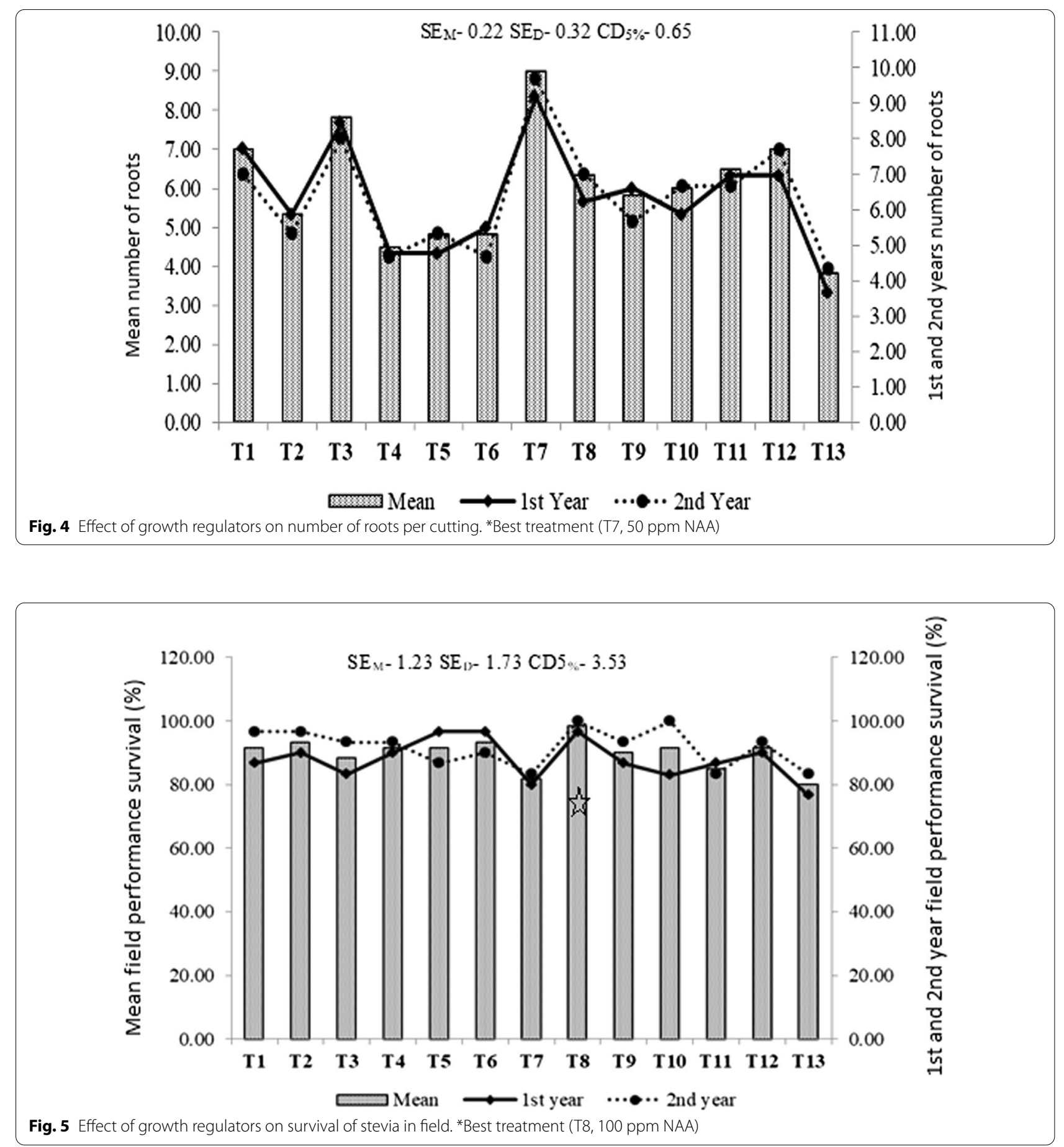

\section{Fresh weight of leaves}

Leaf fresh weight of stevia plants in the field was significantly influenced by the application of growth regulators at 30, 90 and 150 DAT (Table 3). The mean fresh leaf weight of two years at 30, 90 and 150 DAT was significantly higher in growth regulator treatments than control.
The treatments with higher number of leaves were also recorded with higher leaf weight. Application of Toto$\operatorname{root}^{\circledR}$ for 5 mins $\left(T_{12}\right)$ which was recorded with highest number of leaves thus also was recorded with highest mean fresh weight of leaves per plant $(1.58,10.07$ and $21.18 \mathrm{~g}$ at 30,90 and 150 DAT, respectively). Similarly the mean fresh weight of leaves recorded in treatment 
Table 1 Effect of growth regulators on shoot length*

\begin{tabular}{llll}
\hline $\mathbf{T}$ & 30 DAT & 90 DAT & 150 DAT \\
\hline $\mathrm{T}_{1}$ & $19.08^{\mathrm{abc}}$ & $20.90^{\text {cde }}$ & $39.96^{\mathrm{bcd}}$ \\
$\mathrm{T}_{2}$ & $17.38^{\mathrm{bcde}}$ & $19.40^{\mathrm{ef}}$ & $37.58^{\mathrm{bcdef}}$ \\
$\mathrm{T}_{3}$ & $17.86^{\mathrm{bcd}}$ & $22.20^{\text {def }}$ & $34.32^{\text {ef }}$ \\
$\mathrm{T}_{4}$ & $19.80^{\mathrm{ab}}$ & $16.58^{\mathrm{g}}$ & $35.63^{\text {def }}$ \\
$\mathrm{T}_{5}$ & $16.56^{\mathrm{cd}}$ & $18.98^{\mathrm{f}}$ & $37.40^{\text {cdef }}$ \\
$\mathrm{T}_{6}$ & $16.03^{\mathrm{de}}$ & $22.55^{\mathrm{bcd}}$ & $42.93^{\mathrm{b}}$ \\
$\mathrm{T}_{7}$ & $19.28^{\mathrm{abc}}$ & $18.82^{\mathrm{f}}$ & $34.65^{\text {def }}$ \\
$\mathrm{T}_{8}$ & $20.05^{\mathrm{ab}}$ & $20.20^{\text {def }}$ & $40.23^{\mathrm{bc}}$ \\
$\mathrm{T}_{9}$ & $16.93^{\mathrm{cde}}$ & $21.67^{\mathrm{bcd}}$ & $34.40^{\mathrm{ef}}$ \\
$\mathrm{T}_{10}$ & $18.61^{\mathrm{abcd}}$ & $18.72^{\mathrm{f}}$ & $41.60^{\mathrm{bc}}$ \\
$\mathrm{T}_{11}$ & $19.44^{\mathrm{abc}}$ & $21.92^{\mathrm{bcd}}$ & $38.41^{\mathrm{bcde}}$ \\
$\mathrm{T}_{12}$ & $22.54^{\mathrm{a}}$ & $25.62^{\mathrm{a}}$ & $47.93^{\mathrm{a}}$ \\
$\mathrm{T}_{13}$ & $14.80^{\mathrm{e}}$ & $15.78^{\mathrm{g}}$ & $20.65^{\mathrm{g}}$ \\
$\mathrm{SE}_{\mathrm{D}}$ & 0.97 & 0.60 & 1.84 \\
$\mathrm{SE}_{\mathrm{M}}$ & 1.38 & 0.85 & 2.60 \\
$\mathrm{LSD}^{\mathrm{a}}$ & 2.83 & 1.76 & 5.38 \\
\hline
\end{tabular}

Values bearing same letter in the column are not significantly different at $\mathrm{P}=0.01$ of $\mathrm{LSD}$

* Dimension in cm; DAT, days after transplanting; $T$, treatments $\left(\mathrm{T}_{1}\right.$, Cuttings dipped in IBA 50 ppm for $5 \mathrm{~min} ; \mathrm{T}_{2}$, IBA $100 \mathrm{ppm}$ for $5 \mathrm{~min} ; \mathrm{T}_{3}, \mathrm{IBA} 150 \mathrm{ppm}$ for 5 min; $\mathrm{T}_{4}$, IAA $50 \mathrm{ppm}$ for $5 \mathrm{~min}$; $\mathrm{T}_{5}$, IAA $100 \mathrm{ppm}$ for $5 \mathrm{~min} ; \mathrm{T}_{6}$, IAA $150 \mathrm{ppm}$ for $5 \mathrm{~min}$; $\mathrm{T}_{7}$, NAA $50 \mathrm{ppm}$ for $5 \mathrm{~min}$; T8, NAA $100 \mathrm{ppm}$ for $5 \mathrm{~min}$; $\mathrm{T}_{9}$, NAA $150 \mathrm{ppm}$ for $5 \mathrm{~min} ; \mathrm{T}_{10}$, Cuttings smeared in ${ }^{*}$ Totoroot $^{\circledR}$ for one minute; $\mathrm{T}_{11}$, Totoroot $^{\circledR}$ for three minute; $\mathrm{T}_{12}$, Totoroot $^{\circledR}$ for 5 min; $\mathrm{T}_{13}$, Control or without hormone)
$\mathrm{T}_{12}$, was also more than all other growth regulator treatments but not always significant. Similar trend was also observed for other treatments as was recorded for number of leaves per plant.

\section{Fresh weight of shoot and root}

Fresh shoot and root weight of Stevia were significantly influenced by growth regulator treatments (Table 4). The trend of observations recorded for fresh weight of shoot and root were also similar as observed for other growth parameters described above. Treatment $\mathrm{T}_{12}$ (Totoroot $^{\circledR}$ for 5 mins) recorded for highest mean fresh weight of shoot $(5.64,17.68 \& 92.94 \mathrm{~g}$, respectively at 30,90 and 150 DAT $)$ and root $(2.03,3.37 \& 14.39 \mathrm{~g}$, respectively at 30,90 and 150 DAT).

Higher number of branches in Stevia plant was associated with higher number of leaves and higher biomass (Rashid et al. 2013). Totoroot ${ }^{\circledR}$ application for 5 mins produced significantly higher number of branches and leaves per plant over control thus also produced significantly higher amount of biomass in the field. Totoroot ${ }^{\circledR}$ is a commercial formulation of synthetic auxin based on IBA and NAA which on 5 mins of exogenous application to stem cuttings significantly influenced adventitious rhizogenes (Zuffellato-Ribas and Rodrigues 2001) as was evidenced from higher amount of root biomass produced. In case of shoot weight the next best treatment

Table 2 Effect of growth regulators on number of branches and leaves

\begin{tabular}{|c|c|c|c|c|c|c|}
\hline \multirow[t]{2}{*}{$T$} & \multicolumn{3}{|l|}{ NOB } & \multicolumn{3}{|l|}{ NOL } \\
\hline & 30 DAT & 90 DAT & 150 DAT & 30 DAT & 90 DAT & 150 DAT \\
\hline $\mathrm{T}_{1}$ & 0.00 & $3.50^{\text {def }}$ & $8.16^{\mathrm{ef}}$ & $15.17^{\mathrm{abc}}$ & $40.00^{\text {cde }}$ & $70.66^{c}$ \\
\hline $\mathrm{T}_{2}$ & 0.00 & $4.33^{\text {bcde }}$ & $11.16^{\mathrm{cd}}$ & $14.00^{\mathrm{bc}}$ & $43.00^{\text {cde }}$ & $98.50^{b c}$ \\
\hline $\mathrm{T}_{3}$ & $0.33^{b}$ & $5.00^{b c}$ & $15.16^{\mathrm{ab}}$ & $19.17^{\mathrm{ab}}$ & $49.33^{b c}$ & $132.92^{\mathrm{ab}}$ \\
\hline $\mathrm{T}_{4}$ & 0.00 & $2.83^{\mathrm{ef}}$ & $7.97^{\mathrm{ef}}$ & $14.83^{\mathrm{abc}}$ & $36.33^{e f}$ & $69.33^{c}$ \\
\hline $\mathrm{T}_{5}$ & $0.17^{b}$ & $4.17^{\text {cde }}$ & $7.16^{\mathrm{fg}}$ & $12.50^{b c}$ & $56.17^{\mathrm{ab}}$ & $101.00^{b c}$ \\
\hline$T_{6}$ & $0.33^{b}$ & $7.83^{\mathrm{a}}$ & $13.33^{b c}$ & $22.50^{\mathrm{a}}$ & $58.50^{\mathrm{ab}}$ & $148.50^{\mathrm{ab}}$ \\
\hline $\mathrm{T}_{7}$ & 0.00 & $3.17^{\mathrm{ef}}$ & $7.83^{e f}$ & $11.17^{c}$ & $42.50^{\text {cde }}$ & $73.66^{c}$ \\
\hline $\mathrm{T}_{8}$ & $0.50^{\mathrm{b}}$ & $3.67^{\mathrm{def}}$ & $7.50^{f}$ & $13.67^{b c}$ & $50.67^{b c}$ & $104.16^{b c}$ \\
\hline $\mathrm{T}_{9}$ & $0.33^{b}$ & $5.33^{b c}$ & $10.19^{\text {de }}$ & $14.33^{b c}$ & $59.33^{\mathrm{ab}}$ & $136.50^{\mathrm{ab}}$ \\
\hline $\mathrm{T}_{10}$ & $0.67^{a b}$ & $3.00^{e f}$ & $10.33^{\text {de }}$ & $13.33^{b c}$ & $37.33^{\text {def }}$ & $72.66^{c}$ \\
\hline $\mathrm{T}_{11}$ & $0.33^{b}$ & $3.00^{e f}$ & $8.83^{\text {def }}$ & $15.00^{\mathrm{abc}}$ & $48.50^{\mathrm{bcd}}$ & $95.33^{b c}$ \\
\hline $\mathrm{T}_{12}$ & $1.33^{\mathrm{a}}$ & $5.83^{b}$ & $17.66^{a}$ & $23.50^{\mathrm{a}}$ & $65.17^{\mathrm{a}}$ & $159.35^{\mathrm{a}}$ \\
\hline $\mathrm{T}_{13}$ & 0.00 & $2.50^{f}$ & $4.50^{\mathrm{g}}$ & $9.00^{c}$ & $27.50^{f}$ & $62.66^{c}$ \\
\hline$S E_{D}$ & 0.27 & 0.53 & 0.96 & 2.92 & 4.07 & 17.74 \\
\hline $\mathrm{SE}_{\mathrm{M}}$ & 0.39 & 0.75 & 1.36 & 4.14 & 5.76 & 25.09 \\
\hline LSD & 0.80 & 1.54 & 2.82 & 8.38 & 11.88 & 51.79 \\
\hline
\end{tabular}

Values bearing same letter in the column are not significantly different at $P=0.01$ of LSD

NOB, number of branches; NOL, number of leaves; DAT, days after transplanting; $T$, treatments ( $T_{1}$, Cuttings dipped in IBA 50 ppm for 5 min; $T_{2}, I B A 100$ ppm for 5 min; $\mathrm{T}_{3}$, IBA $150 \mathrm{ppm}$ for $5 \mathrm{~min} ; \mathrm{T}_{4}, \mathrm{IAA} 50 \mathrm{ppm}$ for $5 \mathrm{~min} ; \mathrm{T}_{5}$, IAA 100 ppm for $5 \mathrm{~min}$; $\mathrm{T}_{6}$, IAA $150 \mathrm{ppm}$ for $5 \mathrm{~min} ; \mathrm{T}_{7}$, NAA 50 ppm for 5 min; T8, NAA 100 ppm for 5 min; $\mathrm{T}_{9}$, NAA 150 ppm for $5 \mathrm{~min} ; \mathrm{T}_{10}$, Cuttings smeared in "Totoroot ${ }^{\circledR}$ for one minute; $\mathrm{T}_{11}$, Totoroot $^{\circledR}$ for three minute; $\mathrm{T}_{12}$, Totoroot $^{\circledR}$ for 5 min; $\mathrm{T}_{13}$, Control or without hormone) 
Table 3 Effect of growth regulators on fresh weight of leaves

\begin{tabular}{llll}
\hline $\mathbf{T}$ & $\mathbf{3 0}$ DAT & $\mathbf{9 0}$ DAT & $\mathbf{1 5 0}$ DAT \\
\hline $\mathrm{T}_{1}$ & $1.48^{\mathrm{abcd}}$ & $2.74^{\mathrm{efg}}$ & $4.49^{\mathrm{e}}$ \\
$\mathrm{T}_{2}$ & $1.47^{\mathrm{abcd}}$ & $4.22^{\mathrm{bcde}}$ & $13.83^{\mathrm{abcd}}$ \\
$\mathrm{T}_{3}$ & $1.53^{\mathrm{ab}}$ & $5.62^{\mathrm{bc}}$ & $17.63^{\mathrm{ab}}$ \\
$\mathrm{T}_{4}$ & $1.42^{\mathrm{bcd}}$ & $2.57^{\mathrm{efg}}$ & $9.08^{\text {cde }}$ \\
$\mathrm{T}_{5}$ & $1.42^{\mathrm{bcd}}$ & $3.38^{\mathrm{defg}}$ & $10.41^{\mathrm{bcde}}$ \\
$\mathrm{T}_{6}$ & $1.52^{\mathrm{ab}}$ & $5.36^{\mathrm{bc}}$ & $11.17^{\mathrm{bcde}}$ \\
$\mathrm{T}_{7}$ & $1.51^{\mathrm{abc}}$ & $4.77^{\mathrm{bcd}}$ & $13.52^{\mathrm{bcd}}$ \\
$\mathrm{T}_{8}$ & $1.56^{\mathrm{a}}$ & $5.82^{\mathrm{b}}$ & $14.54^{\mathrm{abc}}$ \\
$\mathrm{T}_{9}$ & $1.48^{\mathrm{abcd}}$ & $3.86^{\text {cdef }}$ & $8.15^{\text {cde }}$ \\
$\mathrm{T}_{10}$ & $1.39^{\mathrm{d}}$ & $2.32^{\mathrm{fg}}$ & $13.37^{\mathrm{bcd}}$ \\
$\mathrm{T}_{11}$ & $1.40^{\mathrm{cd}}$ & $3.86^{\text {cdef }}$ & $6.89^{\mathrm{de}}$ \\
$\mathrm{T}_{12}$ & $1.58^{\mathrm{a}}$ & $10.07^{\mathrm{a}}$ & $21.18^{\mathrm{a}}$ \\
$\mathrm{T}_{13}$ & $1.38^{\mathrm{d}}$ & $1.82^{\mathrm{g}}$ & $4.19^{\mathrm{e}}$ \\
$\mathrm{SE}_{\mathrm{D}}$ & 0.05 & 0.89 & 3.56 \\
$\mathrm{SE}_{\mathrm{M}}$ & 0.04 & 0.63 & 2.51 \\
$\mathrm{LSD}$ & 0.12 & 1.83 & 7.35 \\
\hline
\end{tabular}

Values bearing same letter in the column are not significantly different at $\mathrm{P}=0.01$ of $\mathrm{LSD}$

Dimension in grams; DAT, days after transplanting; $T$, treatments $\left(\mathrm{T}_{1}\right.$, Cuttings dipped in IBA $50 \mathrm{ppm}$ for $5 \mathrm{~min} ; \mathrm{T}_{2}$, IBA $100 \mathrm{ppm}$ for $5 \mathrm{~min} ; \mathrm{T}_{3}, \mathrm{BA} 150 \mathrm{ppm}$ for 5 min; $\mathrm{T}_{4}$, IAA $50 \mathrm{ppm}$ for $5 \mathrm{~min} ; \mathrm{T}_{5}$, IAA $100 \mathrm{ppm}$ for $5 \mathrm{~min} ; \mathrm{T}_{6}$, IAA $150 \mathrm{ppm}$ for $5 \mathrm{~min}$; $\mathrm{T}_{7}$, NAA $50 \mathrm{ppm}$ for $5 \mathrm{~min}$; T8, NAA $100 \mathrm{ppm}$ for $5 \mathrm{~min}$; $\mathrm{T}_{9}$, NAA $150 \mathrm{ppm}$ for $5 \mathrm{~min} ; \mathrm{T}_{10}$, Cuttings smeared in ${ }^{*}$ Totoroot $^{\circledR}$ for one minute; $\mathrm{T}_{11}$, Totoroot $^{\circledR}$ for three minute; $\mathrm{T}_{12}$, Totoroot $^{\circledR}$ for 5 min; $\mathrm{T}_{13}$, Control or without hormone) at 150 DAT was $\mathrm{T}_{8}$ (NAA $100 \mathrm{ppm}-75.34 \mathrm{~g}$ ) followed by $\mathrm{T}_{5}$ (IAA $100 \mathrm{ppm}-72.73 \mathrm{~g}$ ) and $\mathrm{T}_{3}$ (IBA $150 \mathrm{ppm}$ $69.28 \mathrm{~g}$ ). These treatments were statistically similar with each other but significantly lesser than Totoroot ${ }^{\circledR} 5$ mins application $\left(\mathrm{T}_{12}\right)$ at 150 DAT. Similarly for root weight at 150 DAT, the best treatments found were $\mathrm{T}_{12}(14.39 \mathrm{~g})$, $\mathrm{T}_{5}(12.83 \mathrm{~g})$ and $\mathrm{T}_{6}$ (IAA $150 \mathrm{ppm}-11.78 \mathrm{~g}$ ) as these treatments were statistically similar with each other.

It was observed that shoot and root growth of Stevia cuttings continued to respond with increasing concentration of IBA from 50 to $150 \mathrm{ppm}$ and increasing exposure time of Totoroot ${ }^{\circledR}$ from one to 5 mins at 150 DAT. This indicates a possibility of further improvement of shoot and root growth of stevia cuttings with higher concentrations of IBA and time exposure of Totoroot ${ }^{\circledR}$ than the highest concentration of IBA (150 ppm) and longest time exposure of Totoroot $^{\circledR}$ (5 mins) used in the present study. Therefore, an optimal endogenous application of plant growth regulators is essential to stimulate growth and differentiation of the stevia cuttings (Hartmann et al. 2010). Growth response of Stevia cuttings up to $100 \mathrm{ppm}$ concentration of IAA and NAA was steadily increasing. Thereafter growth decreased with further increment in concentration of $50 \mathrm{ppm}$. Decrease in root and shoot growth as well increase in mortality rates might be related to photo-toxicity of IAA and NAA $150 \mathrm{ppm}$ as excessive concentrations of auxin inhibit the

Table 4 Effect of growth regulators on mean fresh shoot and root weight ${ }^{*}$

\begin{tabular}{|c|c|c|c|c|c|c|}
\hline \multirow[t]{2}{*}{$T$} & \multicolumn{3}{|l|}{ MFSW } & \multicolumn{3}{|l|}{ MFRW } \\
\hline & 30 DAT & 90 DAT & 150 DAT & $30 \mathrm{DAT}$ & $90 \mathrm{DAT}$ & 150 DAT \\
\hline $\mathrm{T}_{1}$ & $4.41^{\mathrm{bcd}}$ & $9.97^{\text {de }}$ & $35.18^{f}$ & $0.64^{b c}$ & $1.20^{\mathrm{fg}}$ & $6.55^{\mathrm{ef}}$ \\
\hline$T_{2}$ & $4.75^{\mathrm{abcd}}$ & $13.15^{c}$ & $63.38^{\mathrm{cd}}$ & $0.69^{b c}$ & $2.35^{\text {cde }}$ & $9.16^{\text {cde }}$ \\
\hline $\mathrm{T}_{3}$ & $4.73^{\mathrm{abcd}}$ & $14.24^{b c}$ & $69.28_{b c}$ & $1.29^{b}$ & $4.33^{\mathrm{ab}}$ & $9.65^{\mathrm{bcd}}$ \\
\hline $\mathrm{T}_{4}$ & $3.97^{d}$ & $7.76^{e}$ & $56.27^{\mathrm{de}}$ & $0.61^{b c}$ & $1.61^{\mathrm{efg}}$ & $10.58^{b c d}$ \\
\hline $\mathrm{T}_{5}$ & $4.71^{\mathrm{abcd}}$ & $12.00^{c d}$ & $72.73^{b}$ & $0.81^{b c}$ & $1.99^{\mathrm{defg}}$ & $12.83^{\mathrm{ab}}$ \\
\hline$T_{6}$ & $5.32^{\mathrm{ab}}$ & $17.30^{\mathrm{a}}$ & $53.94^{\mathrm{de}}$ & $1.31^{\mathrm{b}}$ & $2.78^{\mathrm{cd}}$ & $11.78^{\mathrm{abc}}$ \\
\hline $\mathrm{T}_{7}$ & $5.43^{\mathrm{a}}$ & $16.27^{a b}$ & $55.28^{\mathrm{de}}$ & $0.66^{b c}$ & $5.18^{\mathrm{a}}$ & $9.13^{\text {cde }}$ \\
\hline $\mathrm{T}_{8}$ & $5.47^{\mathrm{a}}$ & $16.25^{\mathrm{ab}}$ & $75.34^{b}$ & $0.68^{b c}$ & $5.34^{\mathrm{a}}$ & $10.14^{\mathrm{bcd}}$ \\
\hline $\mathrm{T}_{9}$ & $4.94^{a b c}$ & $14.04^{b c}$ & $56.87^{\text {de }}$ & $0.66^{b c}$ & $3.19^{c}$ & $11.25^{b c}$ \\
\hline $\mathrm{T}_{10}$ & $3.93^{d}$ & $10.28^{\mathrm{de}}$ & $56.37^{\text {de }}$ & $0.62^{b c}$ & $1.06^{9}$ & $9.83^{b c d}$ \\
\hline $\mathrm{T}_{11}$ & $4.82^{\mathrm{abcd}}$ & $12.94^{c}$ & $54.75^{e}$ & $0.69^{b c}$ & $2.26^{\text {cdef }}$ & $9.97^{b c d}$ \\
\hline $\mathrm{T}_{12}$ & $5.64^{\mathrm{a}}$ & $17.68^{\mathrm{a}}$ & $92.74^{\mathrm{a}}$ & $2.03^{\mathrm{a}}$ & $3.37^{b c}$ & $14.39^{a}$ \\
\hline $\mathrm{T}_{13}$ & $4.12^{\mathrm{cd}}$ & $6.11^{f}$ & $31.22^{f}$ & $0.54^{c}$ & $1.31^{\mathrm{efg}}$ & $3.96^{f}$ \\
\hline $\mathrm{SE}_{\mathrm{D}}$ & 0.34 & 0.89 & 2.47 & 0.25 & 0.38 & 1.46 \\
\hline $\mathrm{SE}_{\mathrm{M}}$ & 0.48 & 1.25 & 3.50 & 0.35 & 0.54 & 1.03 \\
\hline LSD & 0.97 & 2.59 & 7.21 & 0.71 & 1.12 & 3.03 \\
\hline
\end{tabular}

Values bearing same letter in the column are not significantly different at $P=0.01$ of LSD

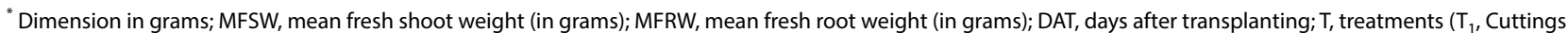
dipped in IBA 50 ppm for 5 min; $T_{2}$, IBA 100 ppm for 5 min; $T_{3}$, IBA 150 ppm for 5 min; $T_{4}$, IAA 50 ppm for 5 min; $T_{5}, I A A 100$ ppm for 5 min; $T_{6}, I^{\prime}$ IAA 150 ppm for 5 min; $T_{7}$, NAA 50 ppm for 5 min; T8, NAA 100 ppm for 5 min; $T_{9}$, NAA 150 ppm for 5 min; $T_{10}$, Cuttings smeared in ${ }^{*}$ Totoroot $^{\circledR}$ for one minute; $T_{11}$, Totoroot $^{\circledR}$ for three minute; $T_{12}$ ' Totoroot ${ }^{\circledR}$ for $5 \mathrm{~min} ; \mathrm{T}_{13}$, Control or without hormone) 
development of roots and shoots and even mortality of stem cuttings (Alcantara et al. 2010).

In contrast IBA was found the best hormonal treatment for root and shoot growth of stevia propagated from cuttings at $7.4 \mathrm{mM}$ concentration by Castañeda-Saucedo et al. (2020) while, López et al. (2016) reported IBA at $1.0 \mathrm{ppm}$ produced higher plants and longer roots in Stevia. Similarly IAA at a concentration of $0.25 \mathrm{mg} / \mathrm{L}$ was reported to help root formation in Stevia (Yücesan et al. 2016). Moreover, a study recommended no hormones for Stevia after observing no influence of hormone application on number of leaves per stevia plant while simultaneously reported significant differences in the survival rate of stevia cutting with application of IBA (Kassahum and Mekonnen 2011). Studies have reported rooting response of Stevia cuttings with higher concentrations (500-1000 mg/L) while either significant decrease or increase with $2000 \mathrm{mg} / \mathrm{L}$ (Khalil et al. 2014; Koppad et al. 2006; Smitha and Umesha 2012; Pigatto et al. 2018). The variation of results might be due to the conditions in which the mother plants were found and agroclimatic conditions in which propagation takes place affect the response of the propagated plants (Zubenko et al. 1991).

Totoroot ${ }^{\circledR}$ with 5 mins exposure significantly improved the growth of Stevia plants as compared to control, IBA, IAA and NAA, while IBA, IAA and NAA application also improved the growth of Stevia plants significantly as compared to control. IBA, IAA and NAA can be applied exogenously as sole or in combination promote cell division and elongation of growing meristematic region while, enhancing translocation of metabolites to the base of the cuttings and nutrient transport to the shoot growing region along with increased hydrolyzing enzymes (Osman et al. 2013; Medina et al. 2016). The improved translocation of nutrients and metabolites improved both root and shoot growth (Ali et al. 2008; Malik 2002; Salisbury and Ross 2006). Cell elongation and division was reflected from increased number, length and biomass of roots and shoots of Stevia cuttings (Gorden and Roger 1980). It is believed that combination of growth regulators in right proportion promotes growth and development of plants more than the application of a sole growth regulator (Malik 2002; Salisbury and Ross 2006) and Totoroot $^{\circledR}$ is a commercial formulation with combination of IBA and NAA.

\section{Conclusions}

The presented study attempted to standardize ex vitro mass regeneration techniques in Stevia rebaudiana vegetatively for Terai agro-climatic zone of northern region of West Bengal, India. Stevia cutting propagated in sand as growing media survived the most and is the best growing medium for propagation of Stevia stem cuttings in the study. Stevia cuttings when dipped in a commercial powdery formulation and grown in sand medium proved ideal for propagating Stevia with cuttings in Terai zone of West Bengal in terms of its survival, rooting, sprout initiation and number of leaves along with uniform and vigorous growth after transplanting in the field. Chemical analysis of ex vitro regenerated plants needs to done for commercial success of the standardized techniques. Zonal specific agronomic practices are to be methodized for successful commercial cultivation of these species in the region. The success of Stevia stem cutting depend on the portion from which the cutting is obtained (i.e. basal, middle or apical), age of the branch and cutting time which is yet to be standardized for the region with its chemical analysis. A cost benefit analysis will be beneficial to popularize commercial cultivation of the species in the region.

\section{Acknowledgements}

Authors are acknowledging the help received form National Medicinal Plants Board, Ministry of AYUSH, Govt. of India, New Delhi under the project entitled "Production of quality planting materials of some important medicinal plants through identification, multiplication, supply of healthy elite genotype and capacity building programmes for improving rural livelihood in Northern part of West Bengal".

\section{Authors' contributions}

AMK, GS and SC designed the current research, organized the experimental, AKM and GS performed the statistical analyses and wrote the draft paper; GS, BR and SC finalize the paper. All authors read and approved the final manuscript.

\section{Funding}

No Funding was received for the study.

Availability of data and materials

The data generated during the study are available from the corresponding author on request.

\section{Declarations}

Ethics approval and consent to participate

Not applicable.

\section{Consent for publication}

Not applicable.

\section{Competing interests}

The authors declare that they have no conflicts of interest among the authors.

\section{Author details}

'Department of Forestry, Uttar Banga Krishi Viswavidyalaya, Pundibari, 736165 Cooch Behar, West Bengal, India. ${ }^{2}$ Department of Seed Science and Technology, Uttar Banga Krishi Viswavidyalaya, Pundibari, 736165 Cooch Behar, West Bengal, India. ${ }^{3}$ Present Address: MS Swaminathan School of Agriculture, Centurion University of Technology and Management, 761211 Parlakhemundi, Gajapati, Odisha, India.

Received: 14 May 2021 Accepted: 27 December 2021

Published online: 06 January 2022 


\section{References}

Abdul Razak UN, Ong CB, Yu TS, Lau LK. In vitro Micropropagation of Stevia rebaudiana Bertoni in Malaysia. Braz Arch Biol Technol. 2014;57:23-8.

Alcantara GB, Oliveira Y, Lima DM, Fogaça A, Pinto F, Biasi A. Efeito dos ácidosnaftalenoacético e indolilbutírico no enraizamento de estacas de jambolão [Syzygium cumini (L.) Skeels]. Rev Bras Plantas Med. 2010;12:317-21. https://doi.org/10.1590/S1516-05722010000300009.

Ali M, Malik AR, Sharma KR. Vegetative propagation of Berberis aristata DC an endangered Himalayan shrub. J Med Plant Res. 2008:2:374-7.

Aquino ME. Stevia, a natural sweetener, is a potential export winner. The Philippine Star. 2011. http://www.phil.com/agriculture/697217/stevia-natur al-sweetener-potential-export-winner. Accessed 2 Sept 2019.

Asghari R. Effect of different plant beds and fertilizers on Stevia (Stevia rebaudiana Bertoni) production. Aust J Crop Sci. 2018;12:51-5.

Bisht A, Irshad S, Rawat AKS, Dwivedi H. Pharmacognostical studies on Saraca asoca (Roxb.) Willd. flower Trop. Plant Res. 2017:4:153-60.

Castañeda-Saucedo Ma C, Tapia-Campos E, del Pilar R-A, Beltrán J. Growth and development of stevia cuttings during propagation with hormones in different months of the year. Plants. 2020;9:294

Cedo ML, Zara R, Gonzaga RA, Famisan A, Baustista N. Enhancing Stevia production through the use of tissue-cultured planting materials and improved farming techniques. 2014; UPLB.DA-BAR.

Das A, Gantait S, Mandal N. Micropropagation of an elite medicinal plant: Stevia rebaudiana Bert. Int J Agric Res. 2011;6:40-8.

De Carvalho MAM, Zaidan LBP. Propagation of Stevia rebaudiana from stem cuttings. Pesqui Agropecu Bras. 1995;30:201-6.

Debnath M. Clonal propagation and antimicrobial activity of an endemic medicinal plant Stevia rebaudiana. J Med Plant Res. 2008;2:45-51.

Fidanza MA, Sanford DL, Beyer DM, Aurentz DJ. Analysis of fresh mushroom compost. Hortic Tech. 2010;20:449-53.

Gantait S, Das A, Mandal N. Stevia: a comprehensive review on ethnopharmacological properties and in vitro regeneration. Sugar Tech. 2015:17:95-106.

Ghani A. Medicinal plants of Bangladesh with chemical constituents and uses. Dhaka: Asiatic Society Bangladesh; 2003. p. 66-434.

Giri B, Kapoor R, Mukerji KG. Influence of arbuscular mycorrhizal fungi and salinity on growth, biomass and mineral nutrition of Acacia auriculiformis. Biol Fertil Soils. 2003:38:170-5.

Gordon RH, Rogor M. An evaluation of new growth retardants on mid-century hybrid lilies. Sci Hortic. 1980;13:349-59.

Grigoriadou K, Krigas N, Sarropoulou V, Papanastasi K, Tsoktouridis G, Maloupa E. In vitro propagation of medicinal and aromatic plants: the case of selected Greek species with conservation priority. In Vitro Cell Dev Biol Plant. 2019. https://doi.org/10.1007/s11627-019-10014-6.

Hartmann HT, Kester D, Davies F, Geneve R. Plant propagation. Principles and practices.8th ed. Prentice Hall, New Jersey, NJ, USA. 2010. 770p.

Hossain MF, Islam MT, Islam MA, Akhtar S. Cultivation and uses of Stevia (Stevia rebaudiana Bertoni): a review. African J Food Agric Nutr Dev. 2017:17:12751-3

Ingle MR, Venugopal CK. Effect of different growth regulators on rooting of stevia (Stevia rebaudiana Bertoni) cuttings. Kr J Agric Sci. 2009;22:460-1.

Jain P, Kachhwaha S, Kothari SL. Improved micropropagation protocol and enhancement in biomass and chlorophyll content in Stevia rebaudiana Bertoni by using high copper levels in the culture medium. Sci Hortic. 2009;119:315-9.

Jefferies P, Gianinazzi S, Perotto S, Turnau K, Barea JM. The contribution of arbuscular mycorrhizal fungi in sustainable maintenance of plant health and soil fertility. Biol Fertil Soils. 2003;37:1-16.

Joseph D, George J. Remedial Potentials of Sweet Leaf A Review on Stevia rebaudiana. Int J Pharm Sci Rev Res. 2019:54:91-5.

Kassahun BM, Mekonnen SA. Effect of cutting position and rooting hormone on propagation ability of Stevia (Stevia rebaudiana Bertoni). Afr J Plant Sci. 2012;6:5-8

Khalil SA, Zamir R, Ahmad N. Selection of suitable propagation method for consistent plantlets production in Stevia rebaudiana (Bertoni). Saudi J Biol Sci. 2014:21:566-73.

Koppad AG, Umarbadshah NK, Gouda M. Effect of growth regulators on propagation of stem cuttings in Stevia rebaudiana. Kar J Agri Sci. 2006;19:740-2.

Lemus-Mondaca R, Vega-Gálvez A, Zura-Bravo L, Ah-Hen K. Stevia Rebaudiana Bertoni, source of a high-potency natural sweetener: a comprehensive review on the biochemical, nutritional and functional aspects. Food Chem. 2012;132:1121-32

López ME، Gil RAE، López ZA. Enraizamiento de esquejes de Stevia rebaudiana Bertoni (Asteraceae) "estevia", aplicandodosiscreciente de ácidoindolbutírico. Arnaldoa. 2016;23:569-76. https://doi.org/10.22497/arnaldoa. 232.23209.

Magangana TP, Stander MA, Makunga NP. Effect of nitrogen and phosphate on in vitro growth and metabolite profiles of Stevia rebaudiana Bertoni (Asteraceae). Plant Cell, Tissue Organ Cult. 2018;134:141-5.

Magevski GC, Czepak MP, Schmildt ER, Alexandre RS, Fernandes AA. Propagação vegetative de espéciessilvestres do gênero Piper, com potencial parauso comoporta enxertosem pimenta-do-reino (Piper nigrum). Revista Brasileira De PlantasMedicinais. 2011;13:559-63. https://doi.org/10.1590/ S1516-05722011000500009.

Malik CP. Plant Physiology. Ludhiana: Kalyani Publishers; 2002. p. 323.

Mandal S, Evelin H, Giri B, Singh V, Kapoor R. Arbuscularmycorrhiza enhances the production of stevioside and rebaudioside- A in Stevia rebaudiana via nutritional and non-nutritional mechanisms. Agric Ecosyst Environ Appl Soil Ecol. 2013;72:187-94.

Medina EL, Rivero AEG, Zavaleta A. Enraizamiento de esquejes de Stevia rebaudiana Bertoni (Asteraceae) "estevia", aplicandodosiscreciente de ácidoindolbutírico. Arnaldoa. 2016;23:569-76. https://doi.org/10.22497/ arnaldoa.232.23209.

Mendaz R, Paolina G, Raaijmalcres JM. The rhizospheremicrobiome: Significance of plant beneficial, plant pathogenic, and human pathogenic microorganisms. FEMS Microbiol Rev. 2013. https://doi.org/10.1111/ 1574-6976.12028

Murthy G, Umesha K, Smitha GR, Krishnamanohar K. Effect of growth regulators and bio-inoculants on rooting and growth of vanilla stem cuttings. Indian J Horticol. 2010;67:90-3.

Ogao-Ogao RJA, Nitural PS, Claveria FG. Vegetative propagation of Stevia (Stevia rebaudiana Bertoni Hemsl) using stem tip cuttings in different growing media. Philipp J Sci. 2017;146:437-43.

Osman M, Samsudin NS, Faruq G, Nezhadahmadi A. Factors affecting microcuttings of Stevia using a mist-chamber propagation box. Sci World J. 2013. https://doi.org/10.1155/2013/940201.

Oviedo-Pereira DG, Alvarenga S, Evangelista-Lozano S, Sepúlveda-Jiménez G, Rodríguez-Monroy M. Micropropagación de Stevia rebaudiana Bertoni, un cultivopromisoriopara México. Biotecnología. 2015;19:147.

Pal P, Kumar R, Guleria V, Mahajan M, Prasad R, Pathania V, Gill B, Singh D, Chand G, Singh B, Singh R, Ahuja P. Crop-ecology and nutritional variability influence growth and secondary metabolites of Stevia rebaudiana Bertoni. BMC Plant Biol. 2015;15:67.

Pande SS, Gupta P. Plant tissue culture of Stevia rebaudiana (Bertoni): a review. J Pharmacognosy Phytother. 2013;5:26-33.

Patwardhan A, Pimputkar M, Mhaskar M, Agarwal P, Barve N, Gunaga R, Vasudeva R. Distribution and population status of threatened medicinal tree Saracaasoca (Roxb) De Wilde from Sahyadri-Konkan ecological corridor. Curr Sci. 2016:111:1500-6.

Pigatto GB, Gomes EN, Tomasi JDC, Ferriani AP, Deschamps C. Effects of indole butyric acid, stem cutting positions and substrates on the vegetative propagation of Stevia rebaudiana Bertoni. Rev Colomb De Cienc Hort. 2018:12:202-11.

Rajashekara. Standardization of vegetative propagation of stevia (Stevia rebaudiana Bertoni) through stem cuttings. M. Sc. (Hort.) Thesis, University of Agricultural Sciences, Bengaluru, India. 2004.

Rashid Z, Rashid M, Inamullah S, Rasool S, Bahar AhF. Effect of different levels of farm yard manure and nitrogen on the yield and nitrogen uptake by stevia (Stevia rebaudiana Bertoni). Afr J Agric Res. 2013;8:3941-5.

Röck-Okuyucu B, Bayraktar M, Akgun IH, Gurel A. Plant growth regulator effects on in vitro propagation and stevioside production in Stevia rebaudiana Bertoni. J Hortic Sci. 2016:51:1573-80.

Salisbury FB and Ross CW. Plant Physiology.CBS Publication. 2006; 540p.

Shahid AK, Zamir R, Ahmad N. Selection of suitable propagation method for consistent plantlets production in Stevia rebaudiana (Bertoni). Saudi J Biol Sci. 2014:21:566-73.

Shukla G, Chakravarty S, Panwar P. Effect of growing media on germination and initial seedling growth of $A$. lebbeck in terai zone of West Bengal. Environ Ecol. 2007:25S:949-50. 
Shukla G, Chakravarty S, Dey AN. Effect of growing media on germination and initial seedling growth of Albizia procera (Roxb) Benth in terai zone of West Bengal. Environ Ecol. 2007;25S:406-7.

Siegel K, Narayan KM, Kinra S. Finding a policy solution to India's diabetes epidemic. Health Affairs Millwood. 2008;27:1077-90.

Sivaram L, Mukundan U. In vitro culture studies on Stevia rebaudiana. In Vitro Cell Dev Biol Plant. 2003;39:520-3.

Smitha GR and Umesha K. Vegetative propagation of Stevia [Stevia rebaudiana (Bertoni) Hemsl.] through stem cuttings. J Trop Agric. 2012;50:72-5.

Vessey JK. Plant growth promoting rhizobacteria as biofertilizers. Plant Soil. 2003;255:571-86.

Yadav AK, Singh S, Dhyani, Ahuja PS. A review on the improvement of stevia [Stevia rebaudiana (Bertoni)]. Can J Plant Sci. 2011;91:1-27.

Yücesan B, Büyükgöçmen R, Mohammed A, Sameeullah M, Altuğ C, Gürel S, Gürel $E$. An efficient regeneration system and steviol glycoside analysis of Stevia Rebaudiana Bertoni, a source of natural high-intensity sweetener. In Vitro Cell Dev Biol Plant. 2016;52:330-7.

Zubenko VF, Rogovskii SV, Chudnovskii BD. Effect of the leafiness of cuttings and of day length on the rooting and transplant growth of Stevia rebaudiana. Plant Physiol Biochem. 1991;23:407-11.

Zuffellato-Ribas KC, Rodrigues JD (2001). Estaquia: umaabordagem dos principaisaspectosfisiologicos. Editora UFPR, Curitiba-PR, 2001; Brazil.

\section{Publisher's Note}

Springer Nature remains neutral with regard to jurisdictional claims in published maps and institutional affiliations.

- fast, convenient online submission

- thorough peer review by experienced researchers in your field

- rapid publication on acceptance

- support for research data, including large and complex data types

- gold Open Access which fosters wider collaboration and increased citations

- maximum visibility for your research: over 100M website views per year

At BMC, research is always in progress.

Learn more biomedcentral.com/submissions 